\title{
PENGARUH PENGGUNAAN LIMBAH KAYU DAN LIMBAH \\ POLIMER SEBAGAI PAPAN KOMPOSIT TERHADAP KUAT \\ LENTUR DAN KADAR AIR PAPAN PARTIKEL
}

Arief Saefudin

\begin{abstract}
Abstrak
Penelitian ini secara operasional bertujuan untuk mengetahui apakah papan komposit dengan menggunakan campuran limbah kayu dan limbah polimer berpengaruh terhadap kuat lentur dan kadar air berdasarkan Standar Nasional Indonesia (SNI) 03-2105-1996, yaitu kuat lentur minimal 80 kg/cm² dan kadar air maksimum 14\%. L Limbah kayu berasal dari industri pengolahan kayu sedangkan limbah polimer berasal dari industri kancing plastik. Perekat yang digunakan adalah perekat urea formaldehida. Pusat penelitian dilakukan di laboratorium keteknikan kayu Jurusan Teknologi Hasil Hutan Fakultas Kehutanan Institut Pertanian Bogor. Metode penelitian menggunakan metode eksperimen dengan satu perlakuan yaitu penggunaan limbah kayu 90\% dan limbah polimer 10\% untuk dijadikan papan komposit.

Hasil penelitian menunjukkan bahwa nilai kadar air papan komposit lebih kecil dari nilai kadar air maksimum Standar Nasional Indonesia dan kuat lentur papan komposit lebih besar dari nilai kuat lentur minimum SNI.03-2105-1996, yang artinya bahwa penggunaan limbah kayu dan limbah polimer untuk pembuatan papan komposit memenuhi standar papan partikel kayu. Kesimpulannya adalah teknologi papan komposit limbah kayu dan limbah polimer ada kemanfaatannya dan perlu ditindak lanjuti, khususnya bagi daerah yang berada di lingkungan industri pengolahan kayu dan industri plastik, juga sebagai tambahan ilmu bagi mahasiswa serta dosen Jurusan Teknik Sipil Fakultas Teknik Universitas Negeri Jakarta khususnya pada mata kuliah Konstruksi Kayu dan IImu Bahan Bangunan.
\end{abstract}

Kata Kunci : limbah kayu, limbah polimer, papan komposit 


\section{Latar Belakang Masalah}

Seiring dengan perkembangan penduduk yang kian pesat, pembangunan perumahanpun terus meningkat, yang berdampak pada kebutuhan akan bahan bangunan terutama kayu. Kebutuhan pasokan kayu baik dari hutan alam, hutan tanaman industri dan hutan rakyat yang melampaui kemampuan kapasitasnya harus segera diantisipasi guna mempertahankan kelestarian lingkungan. Salah satu cara yang dapat ditempuh adalah dengan memanfaatkan limbah kayu secara maksimal dari sisa hasil industri pengolahan kayu, sehingga nilai ekonomis dari limbah kayu itu sendiri semakin bertambah.

Pemanfaatan limbah kayu yang dipergunakan pada penelitian ini adalah berupa serbuk kayu (sawdust) dari sisa penggergajian pada industri pengolahan kayu yang disubstitusikan dengan limbah polimer dari sisa industri kancing plastik sebagai bahan baku utama pembuatan papan komposit.

Penggunaan berbagai macam bahan baku dalam satu bentuk produk komposit sangat memungkinkan di masa yang akan datang, seiring dengan timbulnya berbagai kelangkaan sumberdaya, tuntutan konsumen, pengetahuan dan penguasaan ilmu pengetahuan dan teknologi yang semakin tinggi, serta berbagai faktor lain yang merangsang terciptanya produk komposit berkualitas tinggi dengan bahan baku yang relatif murah, sehingga penelitian ini memiliki kemanfaatan yang positif, baik bagi perkembangan ilmu pengetahuan dan teknologi juga bagi masyarakat umum dan masyarakat kampus yaitu dosen dan mahasiswa.

\section{Perumusan Masalah}

Apakah dengan pencampuran limbah kayu 90\% dan limbah polimer $10 \%$ dapat memenuhi srtandar kuat lentur papan berdasarkan SNI 03-2105-1996 ?

\section{Kegunaan Penelitian}

Penelitian ini berguna bagi Dosen Jurusan Teknik Sipil dalam memberikan sumbangan pemikiran dan referensi dalam Mata Kuliah IImu Bahan Bangunan dan Konstruksi Kayu juga bagi mahasiswa, yaitu sebagai bahan literatur guna penelitian tahap berikutnya kearah yang lebih sempurna. Bagi masyarakat sekitar industri pengolahan kayu dan industri plastik, yaitu

Pengaruh Penggunaan Limbah Kayu Dan Limbah Polimer Sebagai Papan Komposit Terhadap Kuat Lentur Dan Kadar Air Papan Partikel (Arief Saefudin,Dosen Jurusan Teknik Sipil FT- UNJ) 
sebagai wacana untuk menumbuhkan semangat wirausaha dalam memanfaatkan potensi daerahnya dengan pengolahan limbah secara maksimal yang memberikan nilai ekonomis, yang pada gilirannya nanti dapat mendatangkan penghasilan.

\section{Limbah Kayu}

Limbah menurut Imam Hendargo adalah hasil sampingan dari proses produksi yang tidak digunakan yang dapat berbentuk benda padat, cair, gas, debu, suara, getaran, perusakan, dan lain-lain yang dapat menimbulkan pencemaran bilamana tidak dikelola dengan benar. Sedangkan kayu menurut John Stefford dan Guy Mc Murdo adalah produk alami yang menampakkan berbagai variasi dalam segi kualitas maupun sifat. Jadi limbah kayu adalah hasil sampingan dari proses produk alami yang tidak digunakan dan menampakkan berbagai variasi dalam segi kualitas maupun sifat.

Dari jenis lokasi terjadinya limbah, maka limbah kayu dapat dibedakan atas:

a. Limbah panenan kayu, yaitu limbah kayu yang berada di hutan dari hasil sisa panen.

b. Limbah pengolahan kayu, yaitu limbah yang berada di lokasi industri pengolahan kayu, yang dapat berupa serbuk gergaji, sabetan kayu, tatal kayu, potongan log, serutan kayu serta debu kayu, yang penjelasannya adalah sbb:

1) Flake (selumbar), yaitu partikel kecil dengan dimensi tertentu yang dihasilkan dengan alat khusus. Ketebalannya seragam dan sejajar.

2) Shaving (ketaman), yaitu partikel kayu kecil dengan dimensi tidak tentu, ketebalannya bervariasi dan sering mengeriting.

3) Wafer (tatal), yaitu partikel yang mirip dengan flake tetapi lebih besar. Biasanya memiliki ketebalan lebih dari $0,06 \mathrm{~cm}$ dengan panjang lebih dari $2,5 \mathrm{~cm}$.

4) Chip (serpih), yaitu partikel yang dihasilkan dari pemotongan kayu dengan hammer ataupun pisau besar, seperti pembuatan chip untuk pulp kertas.

5) Sawdust (serbuk), yaitu partikel yang dihasilkan dari penggergajian kayu. 
6) Strand (kerekatan), yaitu partikel yang bentuk potongan melintangnya hampir persegi dan mempunyai ukuran panjang empat kali tebalnya.

7) Wood Wool (excelsior), yaitu partikel yang panjang menggulung, mengeriting dan langsing.

\section{Limbah Polimer}

Polimer menurut Fred W. Bill Meyer, Jr dalam bukunya Text Book Of Polymer adalah sebuah molekul besar yang terbentuk oleh ulangan molekul kecil menjadi kesatuan kimia sederhana. Limbah polimer yang digunakan pada penelitian ini adalah limbah polimer plastik yang termasuk dalam high density polyethylene yang merupakan bahan baku produk kancing plastik.

Ditinjau dari sudut kimia, plastik dapat diklasifikasikan atas :

a. Plastik yang bersifat thermoset, yaitu bahan plastik yang tidak dapat dibentuk kembali oleh panas setelah plastik tersebut di buat menjadi produk akhir.

b. Thermoplastik, yaitu bahan plastik yang memiliki sifat fleksibel dan dapat dengan mudah dibentuk kembali menjadi bentuk lain, contohnya polyolefins yang mencakup keluarga polyethylene (PE, HDPE, LDPE, LLDPE) dan polypropylene (PP), polyvinyl chloride (PVC), polystryrene (PS). Klasifikasi thermoplastic ini terbagi lagi menjadi 3 golongan, yaitu:

1) Low density polyethylene (LDPE).

LDPE paling banyak digunakan sebagai plastik kantong karena harganya murah dan dapat dikelim. Memiliki kerapatan 0,910 - 0,925 $\mathrm{g} / \mathrm{cm}^{3}$.

2) Medium density polyethylene (MDPE).

Dengan kerapatan $0,926-0,940 \mathrm{~g} / \mathrm{cm}^{3}$. MDPE bersihat lebih kaku daripada LDPE dan tahan terhadap suhu yang lebih tinggi daripada LDPE

3) High density polyethylene (HDPE).

Dengan kerapatan $0,941-0,956 \mathrm{~g} / \mathrm{cm}^{3}$.

HDPE bersifat lebih kaku daripada MDPE serta lebih tahan terhadap suhu tinggi hingga $120^{\circ} \mathrm{C}$.

Pengaruh Penggunaan Limbah Kayu Dan Limbah Polimer Sebagai Papan Komposit Terhadap Kuat Lentur Dan Kadar Air Papan Partikel (Arief Saefudin,Dosen Jurusan Teknik Sipil FT- UNJ) 


\section{Papan Komposit}

Papan komposit adalah papan yang terbentuk dari dua atau lebih bahan yang berbeda yang membentuk satu kesatuan. Kaitannya dengan penelitian ini adalah bahwa limbah kayu dan limbah polimer yang merupakan dua bahan yang berbeda membentuk satu kesatuan menjadi produk papan yang disebut sebagai papan komposit.

Pemanfaatan limbah sebagai bahan baku papan komposit merupakan salah satu alternatif pemecahan masalah dalam mengatasi eksplorasi sumberdaya alam yang cukup tinggi terutama kayu. Penggunaan berbagai macam bahan baku dalam satu bentuk produk komposit sangat memungkinkan di masa mendatang, terutama bagi negara- negara yang memiliki kelangkaan sumberdaya kayu.

Selain bahan baku limbah kayu dan limbah polimer untuk pembuatan papan komposit, perekat juga merupakan bahan yang digunakan untuk menyatukan campuran material limbah. Perekat yang ideal untuk kayu memiliki persyaratan tertentu, antara lain: harganya murah, mempunyai waktu kadaluarsa yang panjang, cepat mengeras dan cepat matang hanya dalam temperature rendah, mempunyai ketahanan yang tinggi terhadap kelembaban, tahan panas dan mikroorganisme, serta dapat digunakan untuk berbagai keperluan. Dalam pembuatan papan komposit ini, perekat yang digunakan tergolong perekat thermosetting urea formaldehida. Perekat ini merupakan salah satu jenis perekat buatan yang bersifat thermosetting, hasil dari kondensasi dan polimerisasi antara urea dan formaldehida, yang tahan terhadap uap air (moisture resistant), mengeras pada suhu yang relatif rendah $\left(115^{\circ}-127^{\circ} \mathrm{C}\right)$ serta tidak memberikan warna pada produk, tahan rayap dan jamur.

\section{Pembuatan Papan Komposit}

Pembuatan papan komposit pada umumnya dilakukan melalui 7 tahapan utama, yaitu persiapan bahan baku, pengeringan partikel kayu, penyaringan dari kotoran yang menyertai limbah, pencampuran bahan baku dengan perekat, pembuatan lembaran/ mat, pengempaan, dan pengkondisian.

Berikut ini adalah skema pembuatan papan komposit: 


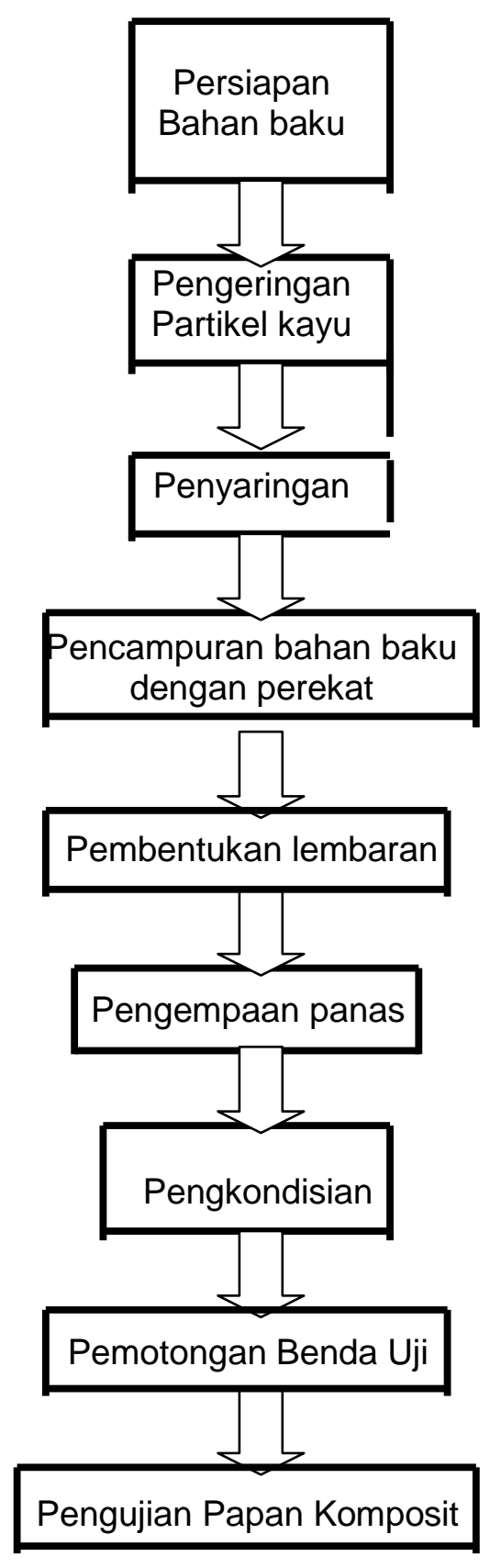

Gambar. 1: Skema Pembuatan Papan Komposit

\section{Pengujian Papan Komposit}

Sebelum dilakukan pengujian sifat fisis dan kuat lentur, maka papan komposit harus dipotong menurut ukuran yang telah ditetapkan oleh SNI 032105-1996.

Pengaruh Penggunaan Limbah Kayu Dan Limbah Polimer Sebagai Papan Komposit Terhadap Kuat Lentur Dan Kadar Air Papan Partikel (Arief Saefudin,Dosen Jurusan Teknik Sipil FT- UNJ) 
Tabel. 1 : Ukuran dan jumlah contoh uji papan partikel

\begin{tabular}{|l|c|c|}
\hline MACAM PENGUJIAN & UKURAN & $\begin{array}{c}\text { JUMLAH CONTOH UJI } \\
\text { PAPAN PARTIKEL }\end{array}$ \\
\hline $\begin{array}{l}\text { 1. Kerapatan } \\
\text { 2. Kadar air }\end{array}$ & $100 \times 100$ & 1 \\
3. Kuat lentur & $50 \mathrm{Lb}(\mathrm{A}+50) \mathrm{Pj}$ & 3 arah panjang dan \\
& $50 \mathrm{Lb} \times 100 \mathrm{Pj}$ & 3 arah lebar \\
4. Kuat pegang sekrup & $50 \times 50$ & 3 \\
5. Kuat tarik lurus & & 3 arah panjang dan \\
permukaan & $50 \mathrm{Lb}(\mathrm{A}+50) \mathrm{Pj}$ & 3 arah lebar \\
6. Kuat lentur kondisi & & 3 \\
basah & $50 \times 50$ & Pengembangan tebal
\end{tabular}

Sumber : SNI 03-2105-1996, Standar Pengujian papan partikel.

Keterangan :

A adalah penumpu (15 kali ketebalan nominal dan kurang dari $150 \mathrm{~mm}$ )

Lb (arah lebar) adalah pemotongan searah lebar papan partikel

Pj (arah panjang) adalah pemotongan arah panjang papan partikel

Kuat lentur papan adalah batas kemampuan papan dalam menerima momen maksimum. Rumusnya adalah:

$$
\mathrm{KL}=\frac{3 \mathrm{BP}}{2 \mathrm{LT}^{2}}
$$

Dimana,

$\mathrm{KL}=\quad$ Kuat lentur papan komposit $\left(\mathrm{kg} / \mathrm{cm}^{2}\right)$

$\mathrm{B}=$ Beban maksimum $(\mathrm{kg})$

$\mathrm{P} \quad=\quad$ Jarak sangga $(\mathrm{cm})$

$\mathrm{L} \quad=\quad$ Lebar $(\mathrm{cm})$

$\mathrm{T} \quad=\quad$ Tebal $(\mathrm{cm})$

Kadar air papan komposit dihitung dari berat awal dan berat akhir setelah mengalami pengeringan dalam oven selama 24 jam pada suhu $104^{\circ} \mathrm{C}$, dengan menggunakan rumus sebagai berikut : 


$$
\mathrm{KA}(\%)=\frac{\mathrm{B}_{1}-\mathrm{B}_{2}}{------} \times 100 \%
$$

Dimana,
$\mathrm{KA}=$ Kadar air (\%)
$\mathrm{B}_{1}=$ Berat awal $(\mathrm{g})$
$\mathrm{B}_{2}=$ Berat kering tanur $(\mathrm{g})$

Syarat mutu sifat fisis dan sifat mekanis papan partikel sesuai standar adalah:

a. Kadar air maksimal $14 \%$

b. Kuat lentur minimal $80 \mathrm{~kg} / \mathrm{cm}^{2}$

c. Kerapatan $0,5-0,9 \mathrm{~g} / \mathrm{cm}^{2}$

\section{Metodologi Penelitian}

Penelitian ini secara operasional bertujuan untuk mengetahui apakah papan komposit dengan menggunakan campuran limbah kayu dan limbah polimer berpengaruh terhadap kuat lentur dan kadar air berdasarkan Standar Nasional Indonesia (SNI) 03-2105-1996, yaitu kuat lentur minimal 80 kg/cm² dan kadar air maksimum 14\%.

Metode yang digunakan pada penelitian ini adalah metode eksperimen, sedangkan variabel penelitiannya terdiri dari dua variabel,yaitu:

Variabel bebas : kuat lentur papan yang menggunakan campuran limbah polimer $10 \%$ dan limbah kayu $90 \%$.

Variabel terikat : kuat lentur papan yang tidak menggunakan campuran limbah polimer dan limbah kayu.

Sampel yang digunakan terdiri dari dua jenis, yaitu sampel utama dengan campuran limbah dan sampel perbandingan yaitu papan komposit tanpa campuran limbah. Sampel dibuat sebanyak 20 buah dengan ukuran $30 \mathrm{~cm} \times$ $30 \mathrm{~cm} \times 1 \mathrm{~cm}$.

Prosedur kerja di laboratorium meliputi dua tahap pekerjaan, yaitu:

1. Tahap Pertama, yakni: pekerjaan pembuatan benda uji

2. Tahap kedua, yakni : pengujian benda uji. Papan komposit yang diuji adalah papan komposit yang telah berumur satu minggu setelah 
pembuatannya. Pengujian yang dilakukan meliputi uji kuat lentur dan uji kadar air

\section{Hasil Penelitian}

1. Penelitian Kuat Lentur

Dari hasil pengujian kuat lentur papan komposit sebanyak 20 buah diperoleh kuat lentur tertinggi $174 \mathrm{~kg} / \mathrm{cm}^{2}$ dan terendah $60 \mathrm{~kg} / \mathrm{cm}^{2}$, sbb:

Tabel. 2 : Distribusi Frekuensi Kuat Lentur Papan Komposit.

\begin{tabular}{|c|c|c|c|}
\hline No & Interval \% & Frekuensi & Frekuensi Relatif \% \\
\hline 1. & $60-79$ & 4 & 20 \\
2. & $80-99$ & 3 & 15 \\
3. & $100-119$ & 3 & 15 \\
4. & $120-139$ & 3 & 15 \\
5. & $140-159$ & 3 & 15 \\
6. & $160-179$ & 4 & 20 \\
\hline \multicolumn{2}{|l|}{ Jumlah } & 20 & 100 \\
\hline
\end{tabular}

Hasil pengujian rata-rata nilai kuat lentur papan komposit dari limbah kayu dan limbah polimer adalah $118 \mathrm{~kg} / \mathrm{cm}^{2}$, sedangkan kuat lentur minimum yang ditetapkan SNI 03-2105-1996 adalah $80 \mathrm{~kg} / \mathrm{cm}^{2}$, yang artinya bahwa penggunaan limbah kayu dan limbah polimer sebagai papan komposit dapat memenuhi standar kuat lentur papan partikel.

2. Penelitian Kadar Air

Dari hasil penelitian kadar air papan komposit sebanyak 20 buah diperoleh nilai kadar air tertinggi $11,9 \%$ dan terendah $8,8 \%$. 
Tabel. 3 : Distribusi Frekuensi Kadar Air Papan Komposit.

\begin{tabular}{|c|c|c|c|}
\hline No & Interval \% & Frekuensi & Frekuensi Relatif \% \\
\hline 1. & $8.8-9.3$ & 4 & 20 \\
2. & $9.4-9.9$ & 4 & 20 \\
3. & $10-10.5$ & 2 & 10 \\
4. & $10.6-11.1$ & 0 & 0 \\
5. & $11.2-11.7$ & 8 & 40 \\
6. & $11.8-12.3$ & 2 & 10 \\
\hline
\end{tabular}

Hasil pengujian rata-rata nilai kadar air papan komposit dari limbah kayu dan limbah polimer adalah 10,5\%, sedangkan kadar air maksimum yang ditetapkan SNI 03-2105-1996 adalah 14\%, sehingga penggunaan limbah kayu dan limbah polimer sebagai papan komposit dapat memenuhi standar kadar air papan partikel.

\section{Kesimpulan}

Dari hasil penelitian, dapat diambil kesimpulan sebagai berikut:

Papan komposit yang terbuat dari limbah kayu dan limbah polimer dapat memenuhi standar papan partikel.

\section{Implikasi}

Implikasi penggunaan papan komposit adalah:

1. Limbah kayu dan limbah polimer dapat dijadikan bentuk lain selain papan komposit.

2. Teknologi pembuatan papan komposit dapat dikembangkan dengan pencampuran bahan lain selain limbah kayu dan limbah polimer.

3. Limbah polimer dapat dimanfaatkan sebagai pengganti pasir urug.

4. Teknologi papan komposit limbah kayu dan limbah polimer dapat dimanfaatkan pada daerah yang berada dekat dengan industri penghasil limbah kayu dan limbah polimer. 


\section{Saran}

Berdasarkan penelitian yang telah dilaksanakan, diajukan saran-saran sebagai berikut:

1. Hasil penelitian sebaiknya dapat diinformasikan kepada mahasiswa dan dosen Jurusan Teknik Sipil Fakultas Teknik Universitas Negeri Jakarta, khususnya pada mata kuliah IImu Bahan Bangunan dan Struktur Kayu.

2. Perlunya pengembangan lebih lanjut mengenai produk papan komposit ke tahap berikutnya yang berkualitas tinggi dengan harga terjangkau.

\section{Daftar Pustaka}

Frick, Heinz. Ilmu Konstruksi Bangunan. Yogyakarta: Kanisius, 1982.

Hendargo. Imam. Kamus Istilah Lingkungan. Jakarta: Rena Pariwara, 1994.

Meyer, Bill, W, Fred, Jr. Text Book Of Polymer. 1984.

Reinhardt. Perekat Untuk Playwood. Jakarta: Direktorat Jenderal Kehutanaan, 1975.

Stefford, John dan Guy Mc Murdo. Teknologi Kayu. Jakarta: Erlangga, 1983.

Supribadi, I, K. IImu Bangunan Gedung. Bandung: Armico, 1993.

Vlack, Van, H, Lawrence. Ilmu dan Teknologi Bahan. Jakarta: Erlangga, 1991.

Wiryomartono, Suwarno. Konstruksi Kayu Jilid I. Yogyakarta: Fakultas Teknik UGM, 1975. 